\title{
Diagnosing of misfire events in compression-ignition engines with the help of vibroacoustic methods in the aspect of OBD system application in diesel locomotives
}

\begin{abstract}
The article concerns the possibilities of use of the method being able to assess of the combustion process and its lack in internal combustion engines of railway traction vehicles, that bases on the use of vibration signal parameters. The paper includes the results of research conducted on the engine test bench with a single cylinder research and compression-ignition engine with direct injection, and tests for the engine of a diesel locomotive in the exploitation condition. Possibility of the vibration signal estimators application to the assessment of a combustion process lack in an internal combustion engine and a high reliability of combustion process diagnostics basing on the above method have been proved.
\end{abstract}

Key words: compression-ignition engine, misfires, combustion, vibroacoustic diagnostics, on-board diagnostics, non-road vehicles

\section{Diagnozowanie wypadania zapłonów w silnikach o zapłonie samoczynnym z wykorzystaniem metod wibroakustycznych $w$ aspekcie zastosowania systemów OBD w lokomotywach spalinowych}

\begin{abstract}
$W$ artykule omówiono możliwości zastosowania metody oceny procesu spalania i jego braku w silnikach spalinowych pojazdów trakcji szynowej, bazującej na wykorzystaniu parametrów sygnału drganiowego. Zamieszczono w nim wyniki badań przeprowadzonych na hamowni silnikowej na jednocylindrowym badawczym silniku o zapłonie samoczynnym (ZS) $z$ wtryskiem bezpośrednim oraz wyniki badań silnika spalinowego lokomotywy w warunkach jej eksploatacji. Wykazano możliwość zastosowania estymat sygnału drganiowego do oceny braku spalania w silniku spalinowym oraz dużą wiarygodność diagnostyki procesu spalania za pomoca powyższej metody.

Słowa kluczowe: silnik o zapłonie samoczynnym, wypadanie zapłonów, spalanie, diagnostyka wibroakustyczna, diagnostyka pokładowa, pojazdy o zastosowaniach pozadrogowych
\end{abstract}

\section{Introduction}

An internal combustion engine is so far the main source of a drive of traction vehicles. Although the present designs of internal combustion engines differ considerably from their oldest prototype, still the main task of an internal combustion engine is to change the energy included in fuel into the mechanical work. Its first development was mainly directed to obtain the largest level of that conversion, what meant the fulfill a postulate of getting by an internal combustion engine as high exploitation parameters values as possible for the widest work conditions area, assuring at the same time the lowest fuel consumption and engine weight. The engine durability and reliability were being taken into consideration. The necessity of a control of the processes taking place in the engine and its technical state has been perceived since the time it was firstly made. At present time, the above propulsion has to cope, parallel to the numerous requirements, with the requirement to make as low ass possible negative influence on the environment regarding toxic compounds as well as noise emissions.

All functional characteristics of the internal combustion engine have been changing during the whole time of its exploitation (influence of inside and outside conditions), causing that its exploitation characteristics have been chang-

\section{Wstęp}

Silnik spalinowy stanowi podstawowe źródło napędu pojazdów trakcyjnych. Mimo iż różni się on znacznie od swojego pierwowzoru, nadal jego podstawowym zadaniem jest zamiana energii zawartej w paliwie na pracę mechaniczną. Jego początkowy rozwój był ukierunkowany w głównej mierze na to, aby powyższa konwersja była jak największa, co przekładało się na postulat uzyskania przez silnik jak największych wartości parametrów eksploatacyjnych w jak najszerszym polu jego pracy, przy zachowaniu jak najmniejszego zużycia paliwa i masy silnika. W procesie projektowania uwzględniano wytrzymałość silnika i jego niezawodność. Od czasu jego powstania dostrzega się konieczność kontroli poprawności przebiegu procesów w nim zachodzących i jego stanu technicznego. Obecnie do wielu wymagań, jakim musi sprostać powyższy napęd dochodzi również wymaganie dotyczące jak najmniejszej uciążliwości silnika dla środowiska naturalnego, zarówno w odniesieniu do emisji składników szkodliwych spalin, jak i hałasu.

W całym okresie eksploatacji następują zmiany wszystkich charakterystyk funkcjonalnych silnika spalinowego (wpływ warunków wewnętrznych i zewnętrznych), powodujące stopniowe pogorszenie charakterystyk eksploatacyj- 
ing gradually, e.g. because of the mass wear of kinematic pairs, deformation or fatigue wear. The continuous process of the engine wear, which intensifies even more during its wrong exploitation, leads to a deterioration of working parameters, disturbances in the proper formation of air-fuel mixture and run of the combustion process, the decrease of durability and in consequence to its damage. Each of the above factors influences on the exhaust emission in a negative way and consequently on the environment and peoples health. Because of that, the diagnostic of technical plants in the whole time of their exploitation process is of the great importance. That is why the continuous control of working of given assemblies, sub-assemblies and elements of the engine has become purposeful to make vehicles meet current emission norms during their all exploitations. In the aftermath of that, requirements concerning of the on-board diagnostic of engines were applied, at first in SI engines, then in CI engines of passenger cars and in light-duty vehicles. The high level of requirements regarding internal combustion engines and obtained benefits caused, that OBD norms and these systems have been using in wider and wider group of vehicles applications. On the basis of trends of emission norms (in the USA and in Europe), the tendency to bring OBD requirements and systems into non-road vehicles applications is being observed at present $[4,5]$. It seems probable that on-board diagnostic will be present in diesel railway traction vehicles in the near future, what confirms usefulness of taking up of OBD system implementation in this group of traction vehicles.

The paper gives the answer for the question about if it is possible to apply vibroacoustic methods for misfire detection in the point of view of realization of the OBD systems which will be using vibration signal parameters to assess the diagnostic engine state and correctness run of processes taking place in the internal combustion engine. The obtained methodology for misfires events diagnoses based on this particular method comprises the detection of the direction of the measuring signal recording, the placement of the vibration transducers, the diagnostic parameter and the conditions for the measurement. It was used then in an exploitation measurements, done for a chosen diesel locomotive engine to check the correctness of the obtained physical rules for this type of the measurement unit and to make bases for the OBD application in these types of sources of a drive.

\section{The basic research at the engine test stand}

\subsection{The research methodology and the test stand}

The research of the misfire detection in combustion engines through vibration methods has been performed based on the active experiment, meaning a deliberate modification of input parameters and observation of their impact on output parameters. Such parameters as engine rotational speed and engine load were chosen as input parameters whereas the acceleration and velocity of vibrations, the pressure in the combustion chamber, fuel consumption and exhaust emissions constituted the output parameters. Fuel consumption and exhaust emissions were neglected in the nych, np. wskutek zużycia masowego par kinematycznych, zużycia deformacyjnego czy zmęczeniowego. Ciągły proces zużycia silnika, który intensyfikuje się jeszcze bardziej podczas jego niewłaściwej eksploatacji, prowadzi do pogorszenia uzyskiwanych przez niego parametrów pracy, zakłócenia prawidłowości tworzenia mieszanki palnej i przebiegu procesu spalania, zmniejszenia trwałości, a w dalszej konsekwencji do jego uszkodzenia. Każdy z powyższych czynników wpływa niekorzystnie na emisję składników szkodliwych spalin z silnika, która ma istotne znaczenie dla ochrony środowiska naturalnego i zdrowia człowieka. Dlatego celowe stało się ciągłe diagnozowanie poprawności funkcjonowania danych zespołów, podzespołów i elementów silnika spalinowego, tak aby pojazd spełniał aktualne normy emisji podczas całego okresu jego eksploatacji. W następstwie tego zastosowano w silnikach wymagania diagnostyki pokładowej, początkowo w silnikach o zapłonie iskrowym (ZI), a następnie w silnikach ZS samochodów osobowych i pojazdów typu LDV (ang. Light Duty Vehicles). Wysoki poziom wymagań w odniesieniu do silników spalinowych i uzyskane korzyści spowodowały, iż systemy OBD (ang. On-Board Diagnostics) i odpowiadające im normy zaczęto stosować w coraz większej grupie pojazdów. Rozpatrując zmiany norm emisji (w USA i Europie), dostrzec można tendencje do coraz szerszego wprowadzania wymagań diagnostyki OBD i takich systemów do pojazdów o zastosowaniach pozadrogowych [4, 5]. Należy spodziewać się, iż w niedalekiej przyszłości diagnostyka pokładowa będzie stosowana w spalinowych pojazdach trakcji szynowej, co potwierdza podjęcie zagadnienia zastosowania systemów OBD w tej grupie pojazdów trakcyjnych.

Artykuł stanowi odpowiedź na pytanie dotyczące możliwości zastosowania metod wibroakustycznych do wykrywania zjawisk wypadania zapłonów w aspekcie realizacji systemów OBD, które będą wykorzystywały parametry sygnału drganiowego do diagnostycznej oceny stanu technicznego silnika i poprawności przebiegu procesów w nim zachodzących. Metodyka diagnozowania wypadania zapłonów oparta na powyższej metodzie zawiera wyznaczenie kierunku rejestracji sygnału pomiarowego, miejsca mocowania przetworników drgań na silniku, parametru diagnostycznego i warunków pomiarowych. Powyższe dane wykorzystano w pomiarach eksploatacyjnych zrealizowanych dla wybranej lokomotywy spalinowej, które wykonano w celu sprawdzenia poprawności uzyskanych wyników dla tego rodzaju obiektu pomiarowego oraz uzyskania podstaw do aplikacji systemu OBD w tej grupie silników.

\section{Badania podstawowe na hamowni silnikowej}

\subsection{Metodyka badań i stanowisko pomiarowe}

Badania wykrywania wypadania zapłonu w silniku spalinowym za pomocą metod drganiowych zrealizowano na podstawie eksperymentu czynnego, który polega na celowej zmianie parametrów wejściowych i obserwacji wpływu tych zmian na wielkości wyjściowe. Parametrami wejściowymi były prędkość obrotowa i obciążenie silnika, natomiast parametry wyjściowe stanowiły wartości przyspieszenia 
further part of this paper. The tests were performed on a chassis dynamometer.

The object of the research was the SB3.1 engine - a single cylinder research engine based on the design of the SW 680 engine. SB3.1 is a 4 stroke compression ignition direct injection engine with a maximum power output of $23 \mathrm{~kW}(\mathrm{n}=2200 \mathrm{rpm})$ and a maximum torque of $109 \mathrm{~N} \cdot \mathrm{m}$ $(\mathrm{n}=1600 \mathrm{rpm})$. The following features of the testing engine are presented below:

- cylinder bore $\times$ piston stroke

- compression ratio

- crankthrow/length

of connecting-rod

- engine displacement

- type of the injection pump

- amount of valves

- inlet valve opening

$\mathrm{D} \times \mathrm{S}=0.127 \times 0.146 \mathrm{~m}$ $\varepsilon=15.75$

$\mathrm{r} / \mathrm{l}=0.262$

$\mathrm{V}_{\mathrm{ss}}=1.852 \cdot 10^{-3} \mathrm{~m}^{3}$ P51T2 - 10.03 II RVO 2

- inlet valve closing $4^{\circ}$ before TDC (Top Dead Cen ter)

$57^{\circ}$ after BDC (Bottom Dead Center)

- outlet valve opening

- outlet valve closing

- injector type

$42^{\circ}$ before BDC

$24^{\circ}$ after TDC

- pressure of the injector

opening multi-hole with 4 holes

- geometric start of fuel delivering

$\mathrm{p}_{\mathrm{wtr}}=17.5 \mathrm{MPa}$

$\alpha_{\mathrm{ptt}}=26^{\circ}$ before TDC

The selection of the engine operating conditions was made basing on the useful rpm and torque range of the tested engine. The operating conditions reflected the engine operation within the load characteristics. The above characteristics were realized for the following engine revolutions: 1000 , 1200, 1500 and $1700 \mathrm{rpm}$ (Table 1).

Additionally, during the research, a working point of the engine defined as: $\mathrm{n}=700 \mathrm{rpm}$ and $\mathrm{M}_{\mathrm{o}}=0 \mathrm{~N} \cdot \mathrm{m}$ was taken into consideration. It reflected the idle operation of the engine. The velocity $\mathrm{n}=1000 \mathrm{rpm}$ reflected the minimum rpm at which the engine could still be loaded and $\mathrm{n}=1700 \mathrm{rpm}-$ the maximum rpm for this type of a tested object. The changes in the engine load were done so as to include 0 , $25,50,75$ and $100 \%$ of the maximum load in the test cycles. For the working points of the engine selected in such a way, the output parameters were recorded in a specified time window. The parameters were recorded in a parallel manner. During the experiment, the constant coolant temperature was maintained at $75^{\circ} \mathrm{C}$ by a peripheral temperature stabilizer unit - AVL 553. In order to produce a misfire, the engine was subjected to a pulse fuel cut-off by a mechanical by-pass valve, fitted in the high pressure fuel conduit, between the injection pump and the injector.

The test measuring points were located on the engine head. The points were selected i prędkości drgań oraz wartości ciśnienia w komorze spalania. Powyższe badania zrealizowano na hamowni silnikowej.

Obiektem badań był jednocylindrowy silnik badawczy typu SB3.1 zbudowany na bazie konstrukcji silnika typu SW 680. Silnik typu SB3.1 jest to 4-suwowy silnik o zapłonie samoczynnym i bezpośrednim wtrysku paliwa do cylindra, który uzyskuje maksymalną moc użyteczną równą $23 \mathrm{~kW}$ (przy $\mathrm{n}=2200 \mathrm{obr} / \mathrm{min}$ ) i maksymalny moment obrotowy równy $109 \mathrm{~N} \cdot \mathrm{m}$ (przy $\mathrm{n}=1600 \mathrm{obr} / \mathrm{min}$ ). Dane badanego silnika spalinowego:

- średnica cylindra $\times$ skok tłoka $\quad \mathrm{D} \times \mathrm{S}=0,127 \times 0,146 \mathrm{~m}$

- stopień sprężania $\varepsilon=15,75$

- iloraz promienia wykorbienia

do długości korbowodu

- objętość skokowa silnika

- rodzaj pompy wtryskowej

- liczba zaworów na cylinder

- otwarcie zaworu dolotowego

$\mathrm{r} / 1=0,262$

$\mathrm{V}_{\mathrm{ss}}=1,852 \cdot 10^{-3} \mathrm{~m}^{3}$ P51T2 - 10.03 II RVO 2

$4^{\circ}$ przed GMP (górne martwe położenie tłoka)

- zamknięcie zaworu dolotowego $57^{\circ}$ po DMP (dolne martwe położenie tłoka)

- otwarcie zaworu wylotowego $\quad 42^{\circ}$ przed DMP

- zamknięcie zaworu wylotowego $24^{\circ}$ po GMP

- rodzaj wtryskiwacza czterootworkowy

- ciśnienie otwarcia wtryskiwacza $\mathrm{p}_{\mathrm{wtr}}=17,5 \mathrm{MPa}$

- geometryczny początek tłoczenia paliwa $\alpha_{\mathrm{ptt}}=26^{\circ}$ przed GMP

Wyboru warunków pracy silnika dokonano, wykorzystując użyteczny zakres wartości prędkości obrotowej i momentu obrotowego, jaki można było uzyskać z obiektu badań. Warunki te odzwierciedlały pracę silnika w ramach charakterystyk obciążeniowych. Powyższe charakterystyki zrealizowano dla prędkości obrotowej : 1000, 1200, 1500 i $1700 \mathrm{obr} / \mathrm{min}$ (tab. 1).

W cyklu badań uwzględniono dodatkowo punkt pracy silnika $\mathrm{n}=700 \mathrm{obr} / \mathrm{min} \mathrm{i} \mathrm{M}_{\mathrm{o}}=0 \mathrm{~N} \cdot \mathrm{m}$, który odpowiadał pracy silnika w warunkach biegu jałowego. Prędkość $n=1000$ obr/ Tabela 1. Punkty pracy silnika typu SB 3.1 uwzględnione w badaniach

\begin{tabular}{|c|c|c|c|c|c|}
\hline \multirow{2}{*}{$\begin{array}{c}\text { Working point/ } \\
\text { Punkt pracy }\end{array}$} & \multicolumn{2}{|c|}{ Parameter/Parametr } & \multirow{2}{*}{$\begin{array}{l}\text { Working point/ } \\
\text { Punkt pracy }\end{array}$} & \multicolumn{2}{|c|}{ Parameter/Parametr } \\
\hline & $\begin{array}{c}\mathrm{n}[\mathrm{rpm}] / \\
n[\mathrm{obr} / \mathrm{min}]\end{array}$ & $\mathrm{M}_{\mathrm{o}}[\mathrm{N} \cdot \mathrm{m}]$ & & $\begin{array}{c}\mathrm{n}[\mathrm{rpm}] / \\
n[\mathrm{obr} / \mathrm{min}]\end{array}$ & $\mathrm{M}_{\mathrm{o}}[\mathrm{N} \cdot \mathrm{m}]$ \\
\hline 1 & \multirow{5}{*}{1000} & 0 & 12 & \multirow{4}{*}{1500} & 22,5 \\
\hline 2 & & 22,5 & 13 & & 45 \\
\hline 3 & & 45 & 14 & & 67,5 \\
\hline 4 & & 67,5 & 15 & & 90 \\
\hline 5 & & 90 & 16 & \multirow{5}{*}{1700} & 0 \\
\hline 6 & \multirow{5}{*}{1200} & 0 & 17 & & 22,5 \\
\hline 7 & & 22,5 & 18 & & 45 \\
\hline 8 & & 45 & 19 & & 67,5 \\
\hline 9 & & 67,5 & 20 & & 90 \\
\hline 10 & & 90 & 21 & 700 & 0 \\
\hline 11 & 1500 & 0 & - & - & - \\
\hline
\end{tabular}


according to the principle that the sensor should be placed closest to the point where the tested process-related vibration signal is generated (Fig. 1).

The vibration transducers were fixed to the engine head through a threaded bore in the head wall. Within the research, the following directions of the vibration signals were analyzed:

a)

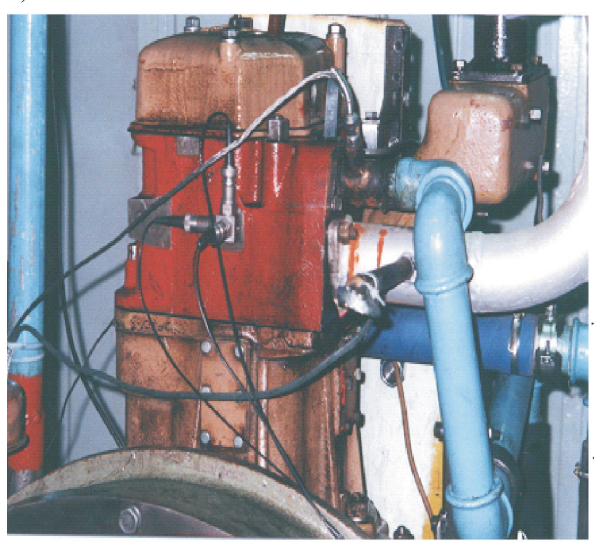

b)

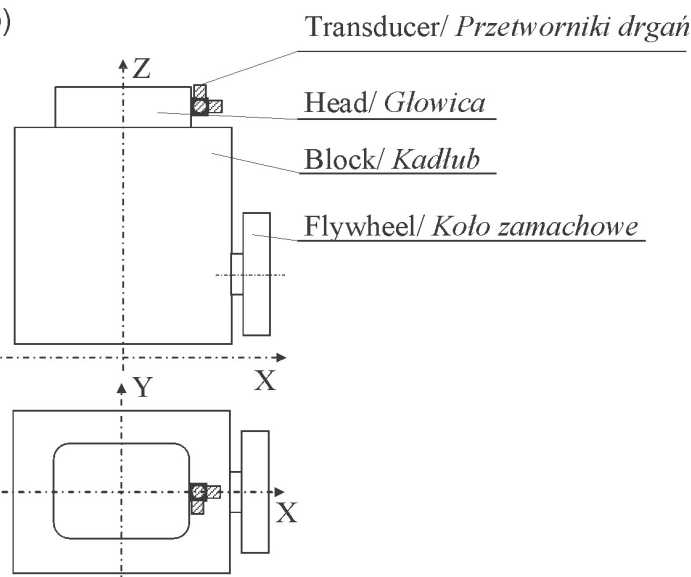

Fig. 1. The placement of the measuring point on the engine: a) the view of the engine with accelerometers, b) the diagram of accelerometer placement

Rys. 1. Lokalizacja punktu pomiarowego na silniku: a) widok silnika z przetwornikami drgań, b) schemat położenia punktów pomiarowych min odpowiadała minimalnej prędkości obrotowej, przy której było możliwe obciążenie silnika, a n = $1700 \mathrm{obr} / \mathrm{min}$ maksymalnej prędkości obrotowej dla tego obiektu badań. Zmiany obciążenia silnika dokonywano w taki sposób, aby objąć cyklem badawczym 0, 25, 50, 75 i 100\% maksymalnej wartości obciążenia. Dla tak dobranych punktów pracy silnika rejestrowano parametry wyjściowe. Parametry te były rejestrowane w sposób równoległy. W trakcie eksperymentu utrzymywano stałą wartość temperatury cieczy chłodzącej na poziomie $75^{\circ} \mathrm{C}$ za pomoca zewnętrznego układu do stabilizacji temperatury typu AVL 553.

$\mathrm{W}$ badaniach wybrano punkty pomiarowe zlokalizowane na głowicy silnika. Punkty te wybrano zgodnie z zasadą, że przetwornik pomiarowy powinien znajdować się jak najbliżej miejsca generacji sygnału drgań związanego parallel to the longitudinal crankshaft axis (direction X), perpendicular to the longitudinal crankshaft and cylinder axes (direction Y), parallel to the longitudinal cylinder axis and, simultaneously, perpendicular to directions $\mathrm{X}$ and $\mathrm{Y}$ (direction $\mathrm{Z}$ ).

The following elements of a measuring unit were used in the tests (Fig. 2):

- cylinder pressure transducer AVL 8QP 505c,

- vibration transducer for each axis (direction $\mathrm{X}, \mathrm{Y}, \mathrm{Z}$ ) by

Brüel \& Kjær, type 4391,

- fuel pressure transducer placed in the high pressure conduit

- Orion IAE 123,

- crank angle encoder AVL 364,

- measuring apparatuses for the basic values i.e.:

- dynamometer AMX 210,

z rozpatrywanym procesem (rys. 1).

Przetworniki drgań zamocowano do głowicy silnika, wykorzystując otwór technologiczny w jej ściance. W ramach badań rejestrowano sygnały drgań w następujących kierunkach: równoległym do osi wzdłużnej wału korbowego (kierunek X), prostopadłym do osi wzdłużnej wału korbowego i cylindra (kierunek Y), równoległym do osi wzdłużnej cylindra i jednocześnie prostopadłym do kierunków X i Y (kierunek Z).

W badaniach zastosowano układ pomiarowy, w skład którego wchodziły (rys. 2):

- przetwornik ciśnienia w cylindrze typu AVL 8QP 505c, - przetworniki drgań dla każdej osi (kierunek X, Y, Z) firmy Brüel \& Kjær typu 4391,
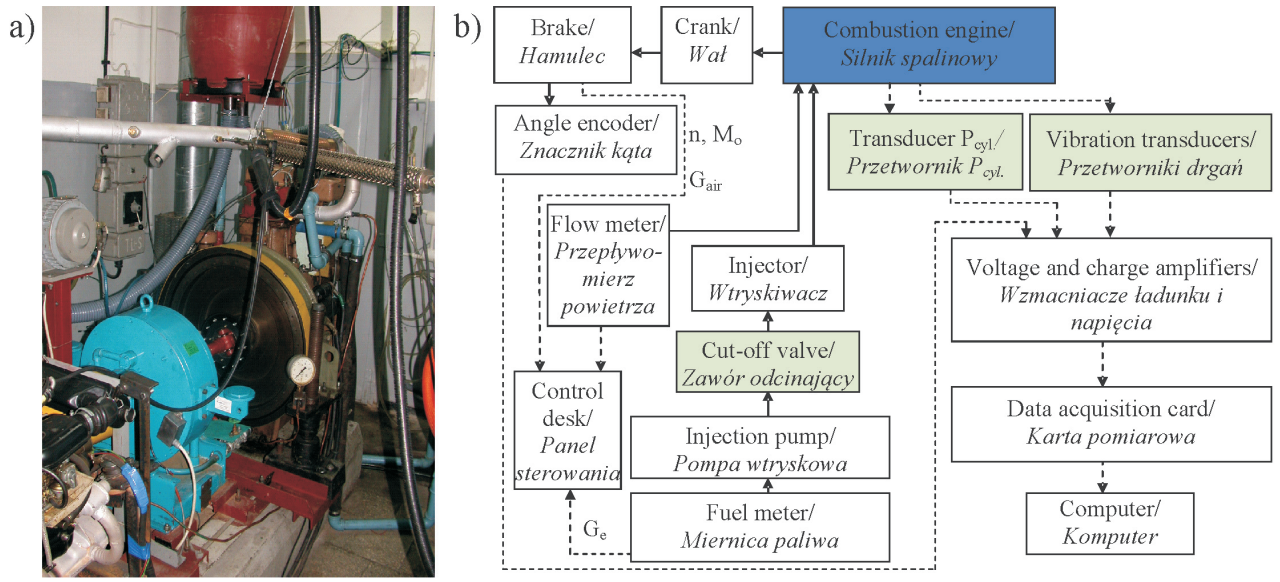

Fig. 2. The view of the test stand (a) and the measuring circuit for recording signals (b) Rys. 2. Stanowisko badawcze (a) i schemat uktadu pomiarowego (b)
- przetwornik ciśnienia paliwa w przewodzie wysokiego ciśnienia typu Orion IAE 123,

- znacznik kąta obrotu wału korbowego typu AVL 364, - aparatura pomiarowa wielkości podstawowych, do których można zaliczyć:

- hamulec elektrowirowy typu AMX 210,

- miernicę paliwa typu AVL 733,

- przepływomierz powietrza typu AVL SENSYFLOW, 
- fuel meter AVL 733,

- air mass flow meter SENSYFLOW,

- coolant temperature stabilizer unit AVL 553,

- coolant and lubricant temperature meter.

Measurement signals obtained from transducers were delivering to amplifiers, in which were amplified and normalized. They were delivering to analog inputs of the data acquisition card then. Measurements signals were filtered inside the card with the help of analog and digital filters, after which were processed from the analog to digital form. Signals obtained in the data acquisition card, in the digital form, were recorded in a computer memory.

\subsection{Test results and analyses}

The purpose of the analysis of the vibration signals obtained during the tests of a single cylinder research $\mathrm{CI}$ engine with direct injection was to ascertain the quantities and the characteristics that characterize the diagnostic signal in a qualitative and quantitive manner. The work contains a description of the signals in the time and value of the processes domains $[1,2]$.

The qualitative assessment of the influence of misfires on the time history of the vibration acceleration, velocity and cylinder pressure was realized for the engine conditions as defined in a Table 1. Based on the said time history, for the whole engine work field, qualitative changes in the vibration acceleration were identified as a result of a misfire. In the Figure 3 the influence of a misfire on the time history runs of accelerations $\left(a_{x}, a_{y}, a_{z}\right)$ and velocities $\left(v_{x}, v_{y}, v_{z}\right)$ of vibrations for each of the recording directions and selected engine working point is presented.

According to the Figure 3, the ignition and a further development of the combustion process results in an abrupt surge of the vibration acceleration amplitude in each of the

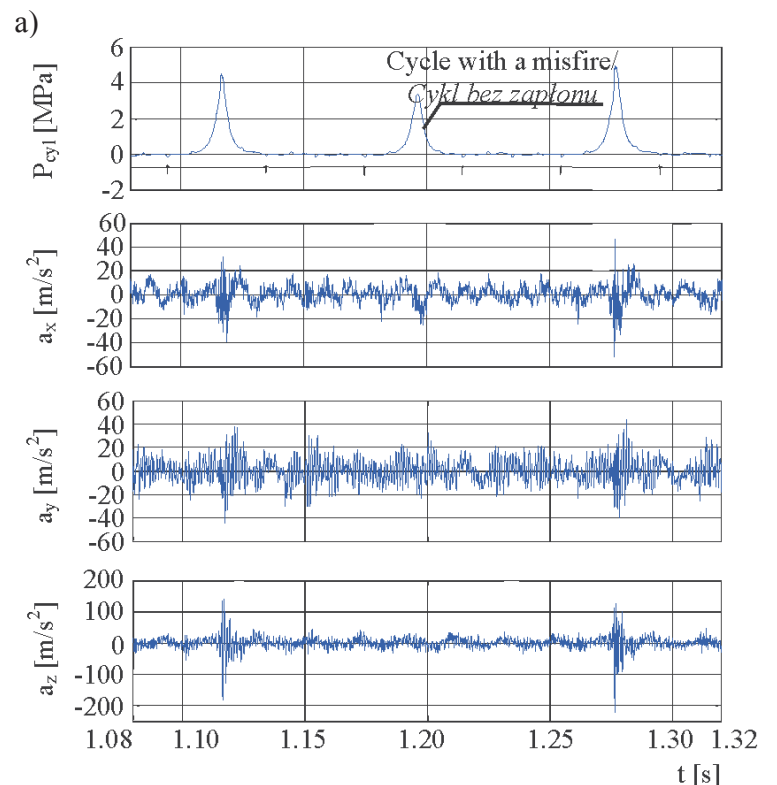

- układ stabilizacji temperatury cieczy chłodzącej typu AVL 553,

- mierniki temperatury cieczy chłodzącej i oleju w układzie smarowania.

Sygnały pomiarowe uzyskane z przetworników kierowano do wzmacniaczy, w których je wzmacniano i normalizowano. Sygnały powyższe były następnie kierowane na wejścia analogowe karty do dynamicznej akwizycji danych. Wewnątrz niej były poddane procesowi filtracji za pomocą filtrów analogowych i cyfrowych, po czym przekształcono je z postaci analogowej w cyfrową. Uzyskane sygnały po wyjściu z karty pomiarowej zapisywano w pamięci komputera.

\subsection{Wyniki badań i analiz}

Celem analizy sygnałów drganiowych uzyskanych podczas badań jednocylindrowego badawczego silnika ZS $\mathrm{z}$ bezpośrednim dostarczaniem paliwa do cylindra było wyznaczenie wielkości i charakterystyk opisujących jakościowo i ilościowo sygnał diagnostyczny. Artykuł zawiera opis sygnałów w dziedzinie czasu i wartości procesów, których podstawy opsano w pracach $[1,2]$.

Ocenę jakościową wpływu zjawiska wypadania zapłonu na przebiegi czasowe przyspieszenia i prędkości drgań oraz ciśnienia w cylindrze zrealizowano dla warunków pracy silnika zdefiniowanych w tab. 1. Na podstawie tych przebiegów stwierdzono jakościowe zmiany sygnałów przyspieszeń drgań wskutek braku zapłonu dla każdego z punktów pracy silnika. Na rysunku 3 przedstawiono wpływ zjawiska wypadania zapłonu na przebiegi czasowe przyspieszeń $\left(\mathrm{a}_{\mathrm{x}}, \mathrm{a}_{\mathrm{y}}\right.$, $\left.\mathrm{a}_{\mathrm{z}}\right)$ i prędkości drgań $\left(\mathrm{v}_{\mathrm{x}}, \mathrm{v}_{\mathrm{y}}, \mathrm{v}_{\mathrm{z}}\right)$ dla każdego $\mathrm{z}$ kierunków rejestracji sygnałów w wybranym punkcie pracy silnika.

Zgodnie z rysunkiem 3 wystąpienie zapłonu w cylindrze i dalszy rozwój procesu spalania powoduje gwałtowny wzrost amplitudy przyspieszenia drgań w każdym z kierunków rejestracji sygnałów pomiarowych. Wartości amplitud sygnałów b)
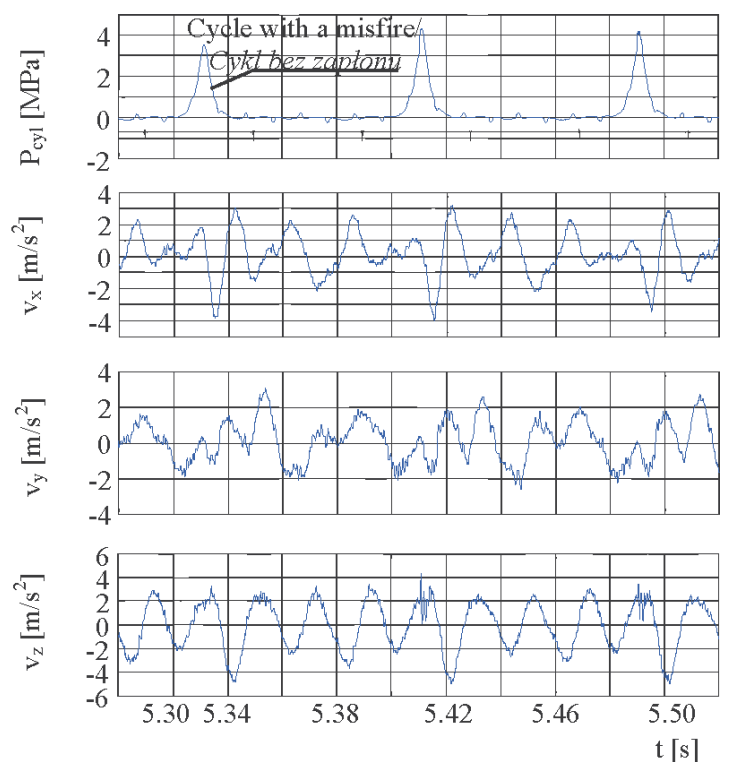

Fig. 3. The time history of the measured signals at $1500 \mathrm{rpm}$ and a torque $0 \mathrm{~N} \cdot \mathrm{m}$ : a) the cylinder pressure $\left(\mathrm{P}_{\text {cyl }}\right)$ and the vibration acceleration in the $\mathrm{X}$, $\mathrm{Y}$ and $\mathrm{Z}$ direction $\left.\left(\mathrm{a}_{\mathrm{x}}, \mathrm{a}_{\mathrm{y}}, \mathrm{a}_{\mathrm{z}}\right), \mathrm{b}\right)$ the cylinder pressure and the vibration velocity in the $\mathrm{X}, \mathrm{Y}$ and $\mathrm{Z}$ direction $\left(\mathrm{v}_{\mathrm{x}}, \mathrm{v}_{\mathrm{y}}, \mathrm{v}_{\mathrm{z}}\right)$

Rys. 3. Przebiegi czasowe sygnałów pomiarowych dla $M_{o}=0 \mathrm{~N} \cdot \mathrm{m}$ i $\mathrm{n}=1500 \mathrm{obr} / \mathrm{min}$ : a) ciśnienia $\mathrm{w}$ cylindrze $\left(P_{\text {cyy }}\right)$ i przyspieszeń drgań $\mathrm{w}$ kierunku $X, Y i Z(a x, a y, a z), b)$ ciśnienia w cylindrze i prędkości drgań w kierunku $X, Y i Z\left(v_{x}, v_{y}, v_{z}\right)$ 
recording directions of the measuring signals. The amplitudes of the vibration acceleration signals in the cycles are tightly connected with the change in the peak value of the cylinder pressure in these cycles. In the case of a misfire, the surge of the amplitude of the vibration signals does not occur (middle cycle at a Fig. 3a). Out of the three directions of the vibration acceleration signal recording, for $\mathrm{Z}$ direction (parallel to the longitudinal axis of the cylinder) the highest values of amplitudes have been obtained at relatively low amplitudes in between the work cycles. The vibration velocity signal turned out useless for the misfire diagnosis.

Differentiation between a cycle and a misfire was possible exclusively for the $\mathrm{Z}$ direction. Too high values of the signal amplitudes between the cycles for other directions, however, rendered that signal was useless and not considerable for the misfire diagnosis. The nature of signal changes at the time history runs for considered parameters at different working points was similar to presented on Fig. 3. The differences were concerned the amplitude values of the cycles with combustion and its lack and of the sequences representing the charge exchanges.

Recorded all time history runs of the measurement signals were taken to time selection process. In the above selection, all recorded signal was divided into signal sequences including single working cycles of the internal combustion engine. Divided measurement signals allowed authors of the paper considering the influence of the single combustion process on the chosen vibration signal parameters and, in a result, calculate differences of these parameters for the proper combustion process and cycles, in which occurred misfire events (Fig. 4).

The selection of the measurement direction, parameter being analyzed and the parameter of the vibroacoustic process that are the most sensitive for misfire occurrences should be done in a quantitive way. The quantitive analysis of the vibration signal has been performed through point measures $[1,2,3]$. The above measures were determined on the basis of the time history of measuring signals. Dimensional and non-dimensional amplitude point measures of vibroacoustic processes were determined. In this paper, example results for: the effective, peak and peak-to-peak values (dimensional point measures) and for shape, peak and impulse factors (non-dimensional point measures) of the vibration signal amplitude have been presented. The above point measures are defined in the Table 2, where: $\mathrm{E}\{\}$ - operator of the mean value after possible peak values of the signal, $t$ - dynamic period (period of dynamic processes duration), $\theta-$ life cycle of the object, $\mathrm{T}$ - signal period, $\mathrm{u}$ - instantaneous signal value.

The single working cycles were divided into cycles with combustion and with misfire events. The chosen point measures for cylinder pressure, acceleration and velocity vibration signals were calculated then. Obtained chosen characteristics of the signal with combustion and without it were being compared, so that it was possible to calculate the relative change of the point measure as a result of a misfire occurrence $\delta_{\mathrm{m}}(\mathrm{u})$, defined as the following equation: przyspieszenia drgań w poszczególnych cyklach pozostają w ścisłym związku ze zmianami wartości szczytowej ciśnienia w cylindrze w tych cyklach. W przypadku braku spalania nie występuje wzrost amplitudy sygnału przyspieszenia drgań (środkowy cykl na rys. 3a). Spośród trzech kierunków rejestracji sygnałów wartości przyspieszenia drgań, dla kierunku Z (równoległego do osi wzdłużnej cylindra) uzyskiwano najwyższe wartości amplitud sygnałów przy relatywnie niewielkich wartościach amplitud między cyklami pracy. Sygnał prędkości drgań okazał się nieprzydatny do diagnostyki zjawisk wypadania zapłonu w cylindrze.

Rozróżnienie cyklu ze spalaniem z cyklem, w którym nie było zapłonu było możliwe jedynie dla kierunku Z. Zbyt duże wartości amplitud sygnału między cyklami zarejestrowane dla innych kierunków sprawiły, że powyższe sygnały były bezużyteczne dla diagnostyki wypadania zapłonów i ich nie rozważano. Charakter zmian sygnałów na przebiegach czasowych dla rozważanych parametrów w różnych punktach pracy silnika był podobny z zaprezentowanym na rys. 3. Różnice dotyczyły wartości uzyskiwanych amplitud dla cykli ze spalaniem i brakiem zapłonu oraz dla odcinków reprezentujących zmiany obciążenia.

Wszystkie zarejestrowane przebiegi czasowe sygnałów poddano selekcji czasowej. W powyższej selekcji każdy zarejestrowany sygnał podzielono na odcinki czasowe zawierające pojedyncze cykle pracy silnika. Podzielone sygnały pomiarowe umożliwiły autorom artykułu rozważenie wpływu pojedynczego procesu spalania na wybrane parametry sygnału drganiowego $i$, jako rezultat, obliczenie różnic powyższych parametrów dla prawidłowego procesu spalania i cykli, w których miało miejsce wypadanie zapłonu (rys. 4).

Wybór kierunku pomiarowego analizowanego parametru oraz parametru procesu wibroakustycznego, które są najbar-

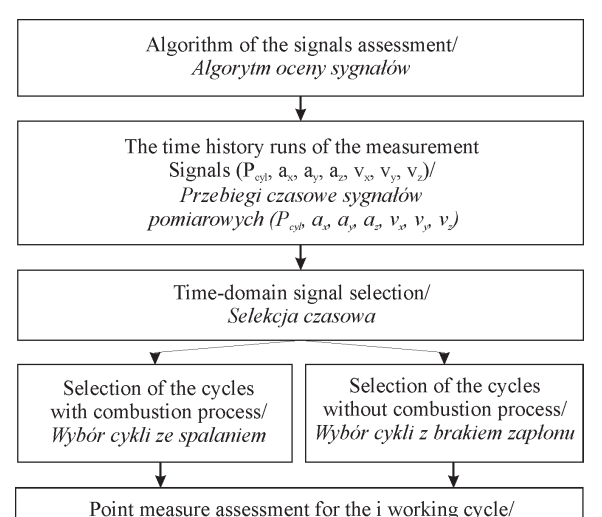
Point measure assessment for the i working cycle/
Ocena miary punktowej dla i-tego cyklu pracy

Calculation of the averaged point measure/ Obliczenie uśrednionej wartości miary punktowej

The relative change of the estimator because
of the misfire event occurence/
Względna zmiana estymatora w wyniku
wystapienia braku zaplomu

Fig. 4. The algorithm of the quantitive assessment of measured signals

Rys. 4. Algorytm ilościowej oceny zmierzonych sygnałów dziej wrażliwe na wystąpienie zjawisk wypadania zapłonu, powinien być zrealizowany $\mathrm{w}$ sposób ilościowy. Ocenę ilościową sygnału drgań przeprowadzono za pomocą miar punktowych [1, 2, 3]. Powyższe miary wyznaczono na podstawie przebiegów czasowych mierzonych sygnałów. Wyznaczono wymiarowe i bezwymiarowe a mplitudowe miary punktowe 
Table 2. Definitions of the example dimensional and non-dimensional point measures considered during analyses of the measurement results[1, 2, 3] Tabela 2. Definicje wybranych wymiarowych i bezwymiarowych miar punktowych rozważanych w analizach wyników pomiarowych [1, 2, 3]

\begin{tabular}{|c|c|}
\hline $\begin{array}{c}\text { Dimensional point measure/Wymiarowa miara } \\
\text { punktowa }\end{array}$ & $\begin{array}{l}\text { Non-dimensional point measure/Bezwymiarowa miara } \\
\text { punktowa }\end{array}$ \\
\hline $\begin{array}{l}\text { Effective value/Wartość skuteczna: } \\
\qquad \mathrm{u}_{\mathrm{sk}}=\mathrm{u}_{\mathrm{sk}}(\theta)=\left[\frac{1}{\mathrm{~T}} \int_{0}^{\mathrm{T}} \mathrm{u}^{2}(\mathrm{t}, \theta) \mathrm{dt}\right]^{1 / 2}\end{array}$ & $\begin{array}{l}\text { Shape ratio/Wspótczynnik ksztaltu: } \\
\qquad \mathrm{K}=\frac{\mathrm{u}_{s k}}{\mathrm{u}_{s c}}=\frac{\left[\frac{1}{\mathrm{~T}} \int_{0}^{\mathrm{T}} \mathrm{u}^{2}(\mathrm{t}, \theta) \mathrm{dt}\right]^{1 / 2}}{\frac{1}{\mathrm{~T}} \int_{0}^{\mathrm{T}}|\mathrm{u}(\mathrm{t}, \theta)| \mathrm{dt}}\end{array}$ \\
\hline 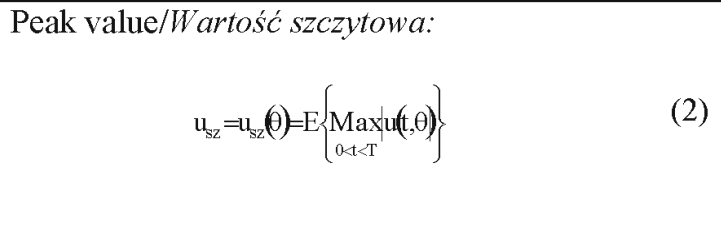 & $\begin{array}{l}\text { Peak factor/Wspólczynnik szczytu: } \\
\qquad \mathrm{C}=\frac{\mathrm{u}_{\mathrm{sz}}}{\mathrm{u}_{\mathrm{sk}}}=\frac{\mathrm{E}\left\{\operatorname{Max}_{0<\mathrm{t}<\mathrm{T}}^{\operatorname{Max}} \mid \mathrm{u}(\mathrm{t}, \theta)\right\}}{\left[\frac{1}{\mathrm{~T}} \int_{0}^{\mathrm{T}} \mathrm{u}^{2}(\mathrm{t}, \theta) \mathrm{dt}\right]^{1 / 2}}\end{array}$ \\
\hline $\begin{array}{l}\text { Peak-to-peak value/Wartość międzyszczytowa: } \\
\qquad \mathrm{u}_{\text {rozst }}=\mathrm{u}_{\text {rozst }}(\theta)=\left|\mathrm{u}_{\max }-\mathrm{u}_{\min }\right|\end{array}$ & $\begin{array}{l}\text { Impulse factor/Wspólczynnik impulsowości: } \\
\qquad \mathrm{I}=\frac{\mathrm{u}_{\mathrm{sz}}}{\mathrm{u}_{\mathrm{sr}}}=\frac{\mathrm{E}\left\{\operatorname{Max}_{0<\mathrm{t}<\mathrm{T}} \mid \mathrm{u}(\mathrm{t}, \theta)\right\}}{\frac{1}{\mathrm{~T}} \int_{0}^{\mathrm{T}} \mid \mathrm{u}(\mathrm{t}, \theta) \mathrm{dt}}\end{array}$ \\
\hline
\end{tabular}

$$
\delta_{\mathrm{m}}(\mathrm{u})=\frac{\left(\mathrm{u}_{\mathrm{m}}\right)_{\text {combustion }}}{\left(\mathrm{u}_{\mathrm{m}}\right)_{\text {misfire }}}
$$

where: $\mathrm{m}$ - type of the point measure, $\mathrm{u}$ - type of the diagnostic parameter (acceleration, velocity).

Misfire events cause that maximum values of the cylinder pressure decrease. For the testing engine and considered working points, misfire event brought about the relative decrease of the peak value of the cylinder pressure $\delta_{\mathrm{sz}}\left(\mathrm{P}_{\mathrm{cyl}}\right)$ from 1.20 to 1.87 (Fig. 5).

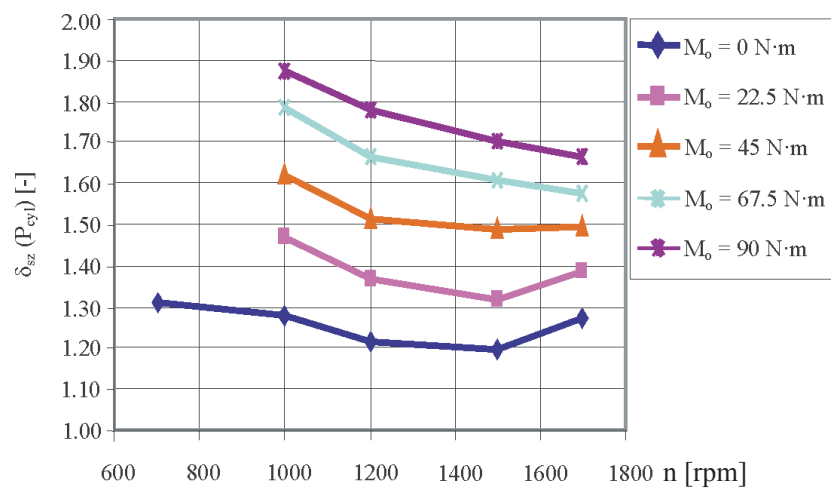

Fig. 5. The relative changes of the peak value of the cylinder pressure $\left(\mathrm{P}_{\text {cyl }}\right)$ as a result of misfires at various engine speeds and torques

Rys. 5. Względna zmiana wartości szczytowej ciśnienia w cylindrze $\left(P_{c y}\right)$ wskutek braku zapłonu dla różnych wartości prędkości obrotowej i momentu obrotowego

Determination of the most sensitive direction for misfire detection and, in the next steps, parameters and quantitive values that should be used for diagnosis of irregularity taking place during combustion process have a huge importance in the point of view of the combustion process diagnostic and procesów wibroakustycznych. W rozważanym artykule zaprezentowano przykładowe wyniki dla: wartości skutecznej, szczytowej i międzyszczytowej (wymiarowe miary punktowe) oraz dla współczynników kształtu, szczytu i impulsowości (bezwymiarowe miary punktowe) amplitudy sygnału drganiowego. Powyższe miary punktowe zdefiniowano w tab. 2, gdzie: $\mathrm{E}\{\}$ - operator wartości średniej po możliwych wartościach szczytowych sygnału, $\mathrm{t}$ - okres dynamiczny (okres trwania procesu dynamicznego), $\theta-$ cykl życia obiektu, T - czas, U - chwilowa wartość sygnału.

Pojedyncze cykle pracy silnika podzielono na cykle ze spalaniem i z brakiem zapłonu. Dla każdego z nich obliczono następnie wybrane miary punktowe dla ciśnienia w cylindrze, przyspieszeń i prędkości drgań. Porównano uzyskane wybrane charakterystyki sygnału ze spalaniem i z jego brakiem, dzięki czemu było możliwe obliczenie względnej zmiany miary punktowej, będącej wynikiem wystąpienia braku zapłonu $\mathrm{w}$ cylindrze $\delta_{\mathrm{m}}(\mathrm{u})$, zgodnie $\mathrm{z}$ zależnością (7):

gdzie: $\mathrm{m}$ - rodzaj miary punktowej, $\mathrm{u}$ - rodzaj parametru diagnostycznego (przyspieszenie, prędkość).

Zjawiska wypadania zapłonu powodują, iż wartości maksymalne ciśnienia w cylindrze zmniejszają się. Dla badanego silnika i rozważanych punktów pracy brak zapłonu powodował względne zmniejszenie wartości szczytowej ciśnienia w cylindrze $\delta_{\mathrm{sz}}\left(\mathrm{P}_{\text {cyl }}\right)$ od 1,20 do 1,87 (rys. 5).

Wyznaczenie najbardziej wrażliwego na brak zapłonu kierunku rejestracji sygnałów pomiarowych oraz, w następnym kroku, parametrów i wartości miar, które powinny być zastosowane do procesu diagnostyki nieprawidłowości zachodzących podczas procesu spalania ma istotne znaczenie z punktu widzenia diagnostyki procesu spalania i opracowania narzędzi, które umożliwią realizację diagnostyki pokładowej w silnikach ZS o różnych zastosowaniach. W celu wyboru właściwego kierunku pomiarowego, parametrów 
also for creation the tools that will make possible on-board diagnosis of the compression-ignition engines in various engines applications. In order to choose the proper direction, parameters and point values of the vibroacoustic signal, the relative changes of the vibration signals at all considered in the research working points and for each working cycles were estimated. In Figure 6, the sensitivities of the vibration signals characteristics on misfire at three measuring directions were presented. The working point with $M_{o}=0 \mathrm{~N} \cdot \mathrm{m}$ represents the worst conditions for misfire detection.

The graphs at the Figure 6 show that $\mathrm{Z}$ direction is the most sensitive and reliable for misfire diagnosis because of the highest relative decrease of the point measures. Analysis i miar punktowych sygnału wibroakustycznego, wyznaczono względne zmiany sygnałów wibroakustycznych dla wszystkich rozważanych w pomiarach punktów pracy silnika i każdego cyklu pracy. Na rysunku 6 przedstawiono wrażliwość miar sygnałów drganiowych na wystąpienie braku zapłonu dla trzech kierunków rejestracji sygnałów pomiarowych. Punkt pracy silnika, gdzie $\mathrm{M}_{\mathrm{o}}=0 \mathrm{~N} \cdot \mathrm{m}$ reprezentuje najmniej korzystne warunki dla diagnostyki wypadania zapłonów.

Na rysunku 6 można dostrzec, iż kierunek Z jest najbardziej wrażliwy i wiarygodny dla diagnostyki wypadania zapłonu z uwagi na największą względną zmianę miar punktowych. Analiza prędkości drgań dla rozważanych warunków pracy silnika wskazuje na niewielką zmianę każdej miary a)

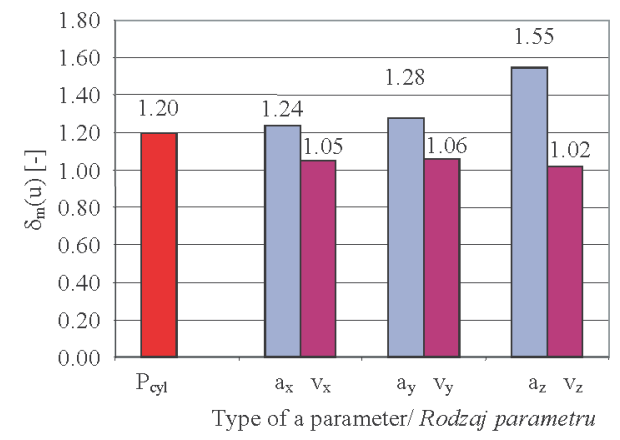

b)

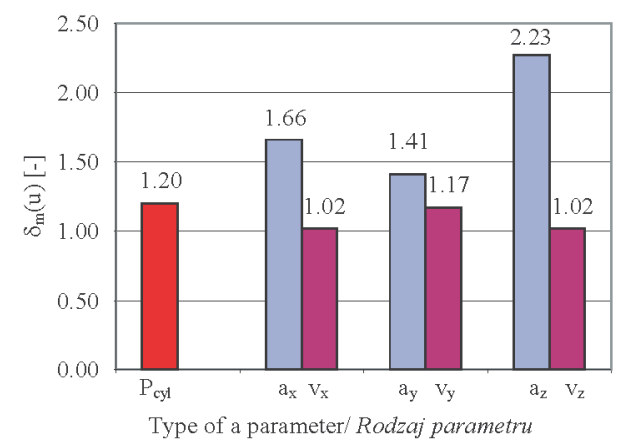

c)

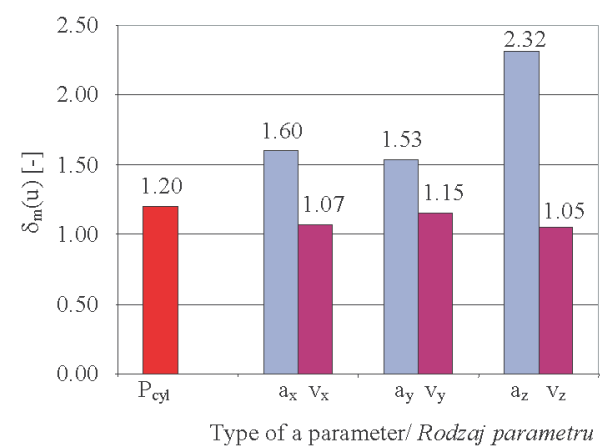

d)

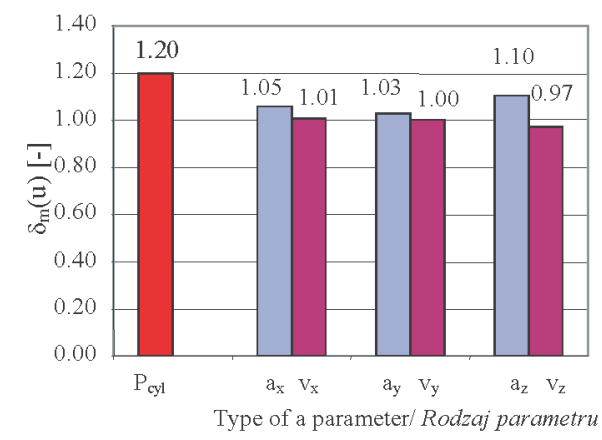

e)

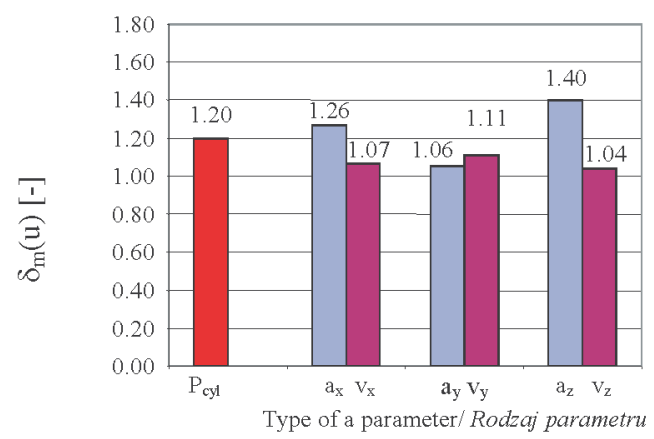

f)

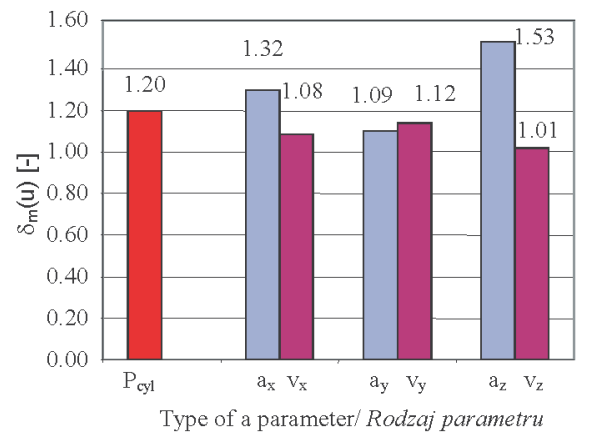

Fig. 6. Relative changes of the: peak value of the cylinder pressure $\left(\mathrm{P}_{\mathrm{cyl}}\right)$, effective values (a), peak values (b), peak-to-peak values (c), shape factors (d), peak factors (e) and impulse factors (f) of the vibration acceleration $\left(a_{x}, a_{y}, a_{z}\right)$ and the vibration velocity $\left(v_{x}, v_{y}, v_{z}\right)$ in the $\mathrm{X}, \mathrm{Y}$ and $\mathrm{Z}$ directions at $\mathrm{n}=1500 \mathrm{rpm}$ and $\mathrm{M}_{\mathrm{o}}=0 \mathrm{~N} \cdot \mathrm{m}$

Rys. 6. Względna zmiana wartości szczytowej ciśnienia w cylindrze $\left(P_{c y}\right)$, wartości skutecznej (a), szczytowej (b), międzyszczytowej (c), współczynnika kształtu (d), szczytu (e) i impulsowości $(f)$ wartości przyspieszenia drgań $\left(a_{x}, a_{y}, a_{z}\right)$ oraz prędkości drgań $\left(v_{x}, v_{y}, v_{z}\right)$ w kierunku $X$, Y i Z dla $n=1500 \mathrm{obr} / \mathrm{min} i M_{o}=0 \mathrm{~N} \cdot \mathrm{m}$ 
of the vibration velocity in all engine working conditions points at the low change of the each vibroacoustic measure when a misfire phenomenon occurs. In the case of vibration velocities, for all directions the different behaviours of the signals were observed. Only vibration accelerations assured to make the proper misfire diagnosis. Comparing vibration characteristics to the obtained sensitivity of the cylinder pressure for misfire events, it is visible that vibration acceleration in the $\mathrm{Z}$ direction is much better for misfire diagnosis than cylinder pressure, even in worse measurement conditions. Accelerations in other directions were also more reliable for diagnosis than the cylinder pressure. Shape, peak and impulse factors presented on the Figure 6 can not be used for misfire diagnosis, because they have to little dynamic of the signal changes in the case of the misfire occurrence. Changes of these point measures were also going in various directions for different working points of the engine.

Taking into consideration all research working points of the engine, the relative decrease of presented point measures (for vibration accelerations in the $\mathrm{Z}$ direction) as a result of the lack of a combustion process is rising when the torque values increase (Fig. 7). The recognition of misfire events among other working cycles is much better in these conditions than for the peak value of a cylinder pressure.

a)

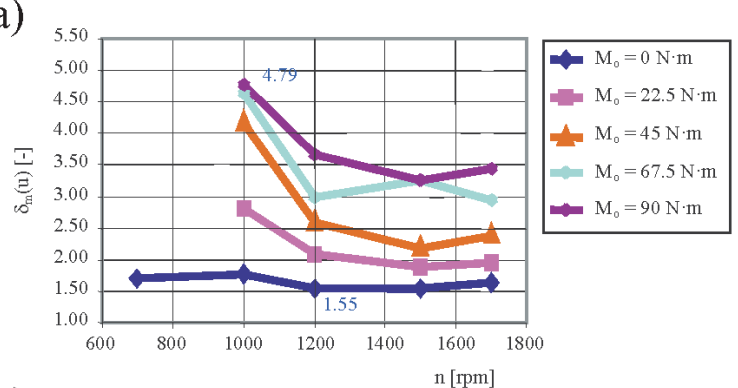

b)

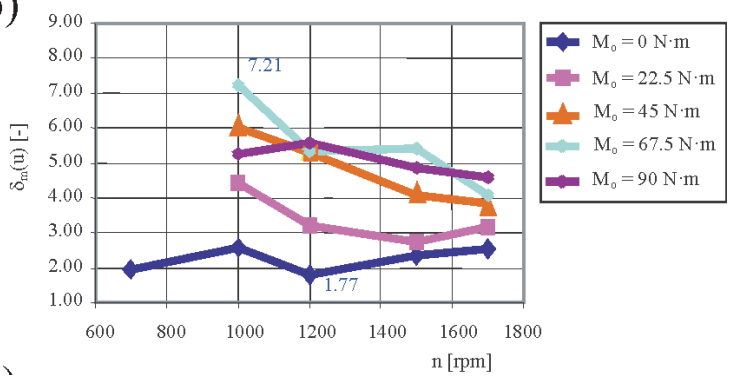

3. The research at the diesel locomotive

\subsection{The research methodology and the test stand}

The measurements were conducted on a 12-cylinder, compression-ignition and direct injection engine of the diesel locomotive, a type SU45 (Fig. 8), with the following features:

engine type

cylinder bore $\times$ piston stroke

compression ratio

engine displacement
2112 SSF, 4-stroke

$\mathrm{D} \times \mathrm{S}=0.21 \times 0.23 \mathrm{~m}$

$\varepsilon=11,3$

$\mathrm{V}_{\mathrm{ss}}=96.6 \cdot 10^{-3} \mathrm{~m}^{3}$ wibroakustycznej w wyniku wystąpienia braku zapłonu. Zaobserwowano różne zachowanie się sygnałów prędkości drgań dla każdego z rejestrowanych kierunków pomiarowych. Jedynie przyspieszenia drgań zapewniały prawidłową diagnozę braku zapłonu. Porównując charakterystyki wibroakustyczne z uzyskaną wrażliwością sygnału ciśnienia w cylindrze na brak zapłonu, można dostrzec, że przyspieszenie drgań w kierunku Z jest znacznie lepsze dla diagnostyki wypadania zapłonu niż sygnał ciśnienia w cylindrze, nawet w przypadku najmniej korzystnych warunków pomiarowych. Przyspieszenia drgań dla pozostałych kierunków rejestracji sygnałów były również bardziej wiarygodne dla procesu diagnostyki niż sygnał ciśnienia w cylindrze. Współczynniki kształtu, szczytu i impulsowości, zaprezentowane na rys. 6 , nie mogą być zastosowane do diagnostyki braku zapłonu $\mathrm{z}$ uwagi na niewielką dynamikę zmian sygnału w przypadku zaistnienia zjawiska wypadania zapłonu. Powyższe zmiany odnotowano dla różnych kierunków rejestracji i punktów pracy silnika.

Biorąc pod uwagę wszystkie rozważane punkty pracy silnika, można stwierdzić, że względne zmniejszenie powyższych miar punktowych (dla przyspieszenia drgań w kierunku Z) w wyniku braku spalania zwiększa się wraz ze wzrostem wartości momentu obrotowego (rys. 7). Rozpoznanie zjawisk wypadania zapłonu wśród cykli ze spalaniem jest znacznie lepsze w powyższych warunkach niż dla wartości szczytowej ciśnienia w cylindrze.

c)

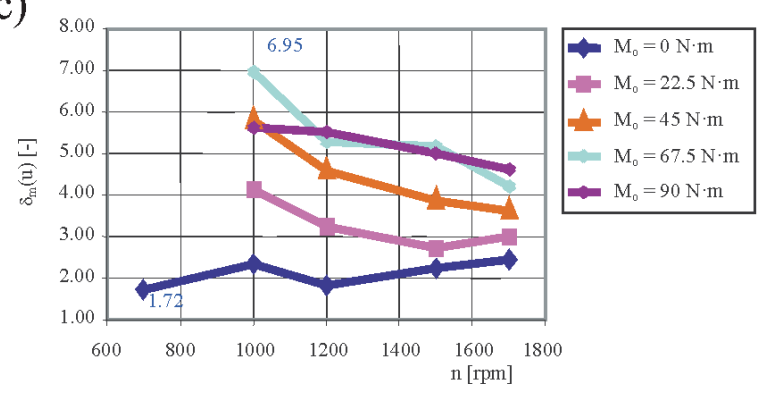

Fig. 7. The relative decrease of the effective (a), peak (b) and peak-to peak (c) values of the vibration acceleration in the $\mathrm{Z}$ direction as a result of the misfire occurrence for various engine speeds and torques

Rys. 7. Względne zmniejszenie wartości skutecznej (a), szczytowej (b) i międzyszczytowej (c) przyspieszenia drgań w kierunku $Z$ w wyniku braku zapłonu dla różnych wartości prędkości obrotowej i momentu obrotowego

\section{Badania lokomotywy spalinowej}

\subsection{Metodyka badań i stanowisko pomiarowe}

Badania przeprowadzono na dwunastocylindrowym silniku ZS z bezpośrednim dostarczaniem paliwa do cylindra lokomotywy spalinowej typu SU45 (rys. 8). Dane techniczne silnika:

rodzaj silnika

2112 SSF, 4-suwowy

średnica cylindra $\times$ skok tłoka

stopień sprężania

$\mathrm{D} \times \mathrm{S}=0,21 \times 0,23 \mathrm{~m}$

objętość skokowa silnika $\varepsilon=11,3$

$\mathrm{V}_{\mathrm{ss}}=96,6 \cdot 10^{-3} \mathrm{~m}^{3}$ 
maximum effective power cylinder system mean effective pressure amount of valves inlet valve opening inlet valve closing outlet valve opening outlet valve closing pressure of the injector opening geometric start of fuel delivering
$1655 \mathrm{~kW}$ by $1500 \mathrm{rpm}$ $\mathrm{V} 12$

$\mathrm{p}_{\mathrm{e}}=1.37 \mathrm{MPa}$

$35^{\circ}$ before TDC

$23^{\circ}$ after BDC

$25^{\circ}$ before BDC

$53^{\circ}$ after TDC

$\mathrm{p}_{\mathrm{wtr}}=26 \mathrm{MPa}$

$\alpha_{\mathrm{ptt}}=32^{\circ}$ before TDC znamionowa moc użyteczna

układ cylindrów

średnie ciśnienie użyteczne

liczba zaworów na cylinder otwarcie zaworu dolotowego zamknięcie zaworu dolotowego otwarcie zaworu wylotowego zamknięcie zaworu wylotowego ciśnienie otwarcia wtryskiwacza geometryczny początek tłoczenia paliwa
$1655 \mathrm{~kW}$ przy 1500 $\mathrm{obr} / \mathrm{min}$ V12

$\mathrm{p}_{\mathrm{e}}=1,37 \mathrm{MPa}$ 4

$35^{\circ}$ przed GMP

$23^{\circ}$ po DMP

$25^{\circ}$ przed DMP

$53^{\circ}$ po GMP

$\mathrm{p}_{\mathrm{wtr}}=26 \mathrm{MPa}$

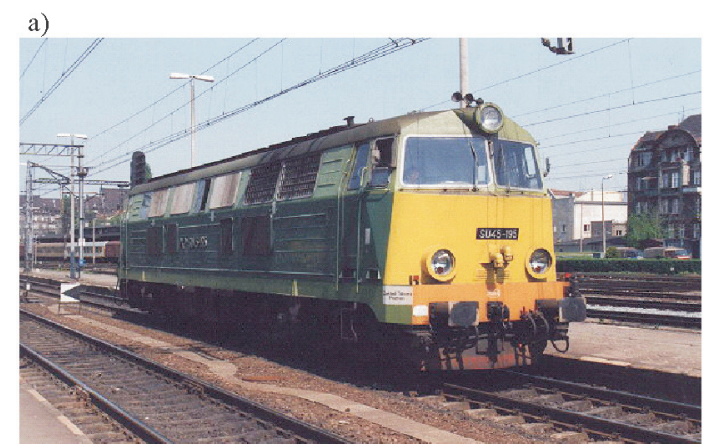

b)

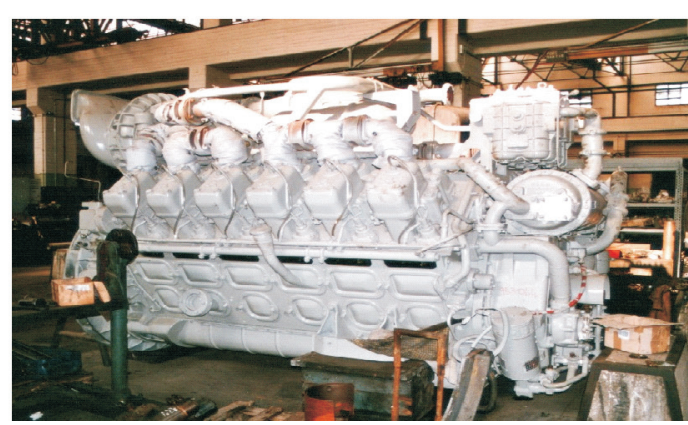

Fig. 8. The view of the SU45 diesel locomotive (a) and its engine (b)

Rys. 8. Lokomotywa spalinowa typu SU45 (a) oraz zastosowany w niej silnik spalinowy (b)

The selection of the operating conditions of the engine was made basing on the useful rpm and torque range of the tested engine, corresponding with the exploitation conditions. The measurements were divided into two parts. In the first of them all cylinders of the one row were taken into consideration to check if it is possible to use vibration characteristics in the assessment of the combustion process run for an engine being used in traction vehicles. This stage was also used to see the differences in sensibility of the vibration signal in each working cylinder. This helped to determinate the best and worst conditions for misfire detection basing on vibration methods. The second research stage was used to determine the differences between signals with combustion and a misfire for different working points (power changes) for 3 cylinders taken from the prior stage. In the first stage the following velocities were taken into consideration: 700, 900, 1080, 1300 and $1500 \mathrm{rpm}$. The following effective power was being obtained: $\sim 0$ (idling run), 252, 460, 580, $667 \mathrm{~kW}$. In the second research stage all velocities and torques defined with the locomotive regulating unit position were taken as the working points.

The test measuring points were located on the engine head. The points were selected according to the principle that the sensor should be placed closest to the point where the tested process-related vibration signal is generated (Fig. 9).

The following elements of a measuring unit were used in the tests (Fig. 10):
Wybór warunków pracy silnika zrealizowano na podstawie użytecznego zakresu prędkości obrotowej i momentu obrotowego badanego silnika, odpowiadającego warunkom jego eksploatacji. Pomiary podzielono na dwa etapy. W pierwszym z nich uwzględniono wszystkie cylindry jednego rzędu, w celu określenia możliwości zastosowania charakterystyk wibroakustycznych do oceny przebiegu procesu spalania w silniku stosowanym w pojazdach trakcyjnych. Powyższy etap zrealizowano w celu określenia różnic we wrażliwości sygnału drganiowego w każdym z cylindrów. Działania te umożliwiły wyznaczenie najbardziej i najmniej korzystnych warunków wykrywania braku spalania z zastosowaniem metod drganiowych. Drugi etap badań zastosowano w celu wyznaczenia różnic między sygnałami dla procesu spalania i braku zapłonu dla różnych punktów pracy (zmian mocy użytecznej) i 3. cylindrów wybranych w pierwszym etapie, w którym uwzględniono następujące prędkości obrotowe silnika: 700, 900, 1080, 1300 i 1500 obr/min. Badania przeprowadzono dla następujących wartości mocy użytecznej: 0 (bieg jałowy), 252, 460, 580, $667 \mathrm{~kW}$. W drugim etapie badań uwzględniono wszystkie wartości prędkości obrotowej i momentu obrotowego określone daną pozycją nastawnika jazdy lokomotywy.

Punkty pomiarowe zlokalizowano na głowicy silnika. Powyższe punkty wybrano zgodnie z zasadą, że przetwornik pomiarowy powinien być umieszczony jak najbliżej miejsca generacji sygnału drganiowego odnoszącego się do danego procesu (rys. 9). 
a)

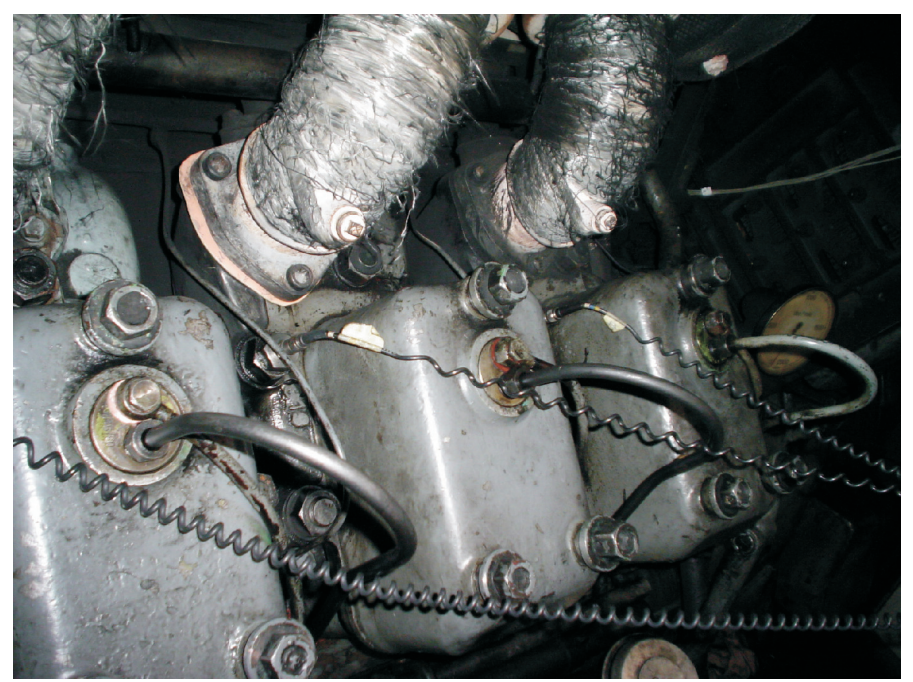

b)

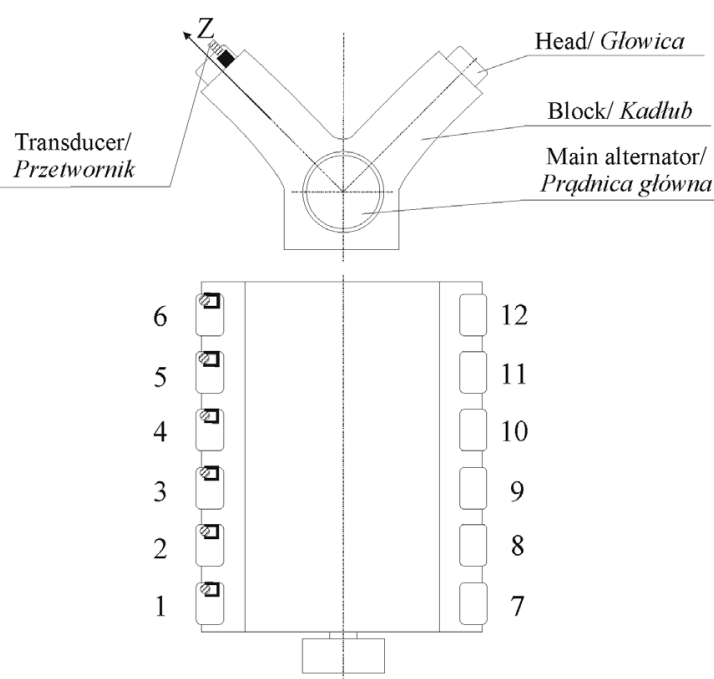

Fig. 9. The placement of the measuring points on the engine: a) the view of the engine with accelerometers, b) the diagram of accelerometer placement Rys. 9. Rozmieszczenie punktów pomiarowych na silniku: a) silnik wraz z przetwornikami, b) schemat rozmieszczenia przetworników

- vibration transducers for the Z direction by Brüel \& Kjær, type 4391 ,

- vibration signals calibration unit by Brüel \& Kjær 4294,

- crank angle encoder by Wobit MOK,

- charge amplifier by NEXUS, type 2692,

- data acquisition card by National Instruments, type PCI-4472 ,

- water resistor with the control system,

- coolant and lubricant temperature meter.

The flow of the measuring data was similar to this from the measurements conducted during the basic research at the engine test stand. The torque and power was being measured and controlled with the help of the water resistor stand.

\subsection{Test results and analyses}

The first and second stage of the measurements at the diesel locomotive pointed that the vibration signal can be used to the on-line assessment of the misfire events which occur during normal working of an internal combustion engine. The ignition causes the impulse changes of the vibration signal amplitudes and the combustion process has its representation in a vibration signal. The signal is distinct in each working cycle independently from the cylinder number, what confirms the reliability of the method in relation to detection procedures being done for multi-cylinder compression-ignition engines (Fig. 11).

Changes of the engine effective power were causing the changes dynamics of point estimators of the vibration signal. It points that vibration signal parameters follow with the power changes (torque and velocity). The increase of the effective power was causing that the peak and peak-to-peak values in each cylinder were increasing. The point estimator in the each engine working point was being related to the point value obtained at idling conditions (Fig. 12).
W badaniach zastosowano układ pomiarowy, w skład którego wchodziły (rys. 10):

- przetworniki drgań w kierunku Z firmy Brüel \& Kjær, typ 4391,

- kalibrator sygnałów drganiowych firmy Brüel \& Kjær 4294,

- znacznik kąta obrotu wału korbowego by Wobit MOK,

- wzmacniacz ładunku NEXUS, typ 2692,

- karta do dynamicznej akwizycji danych firmy National Instruments, typ PCI-4472,

- opornik wodny wraz z układem sterowania,

- układ do pomiaru temperatury cieczy chłodzącej i oleju silnikowego.

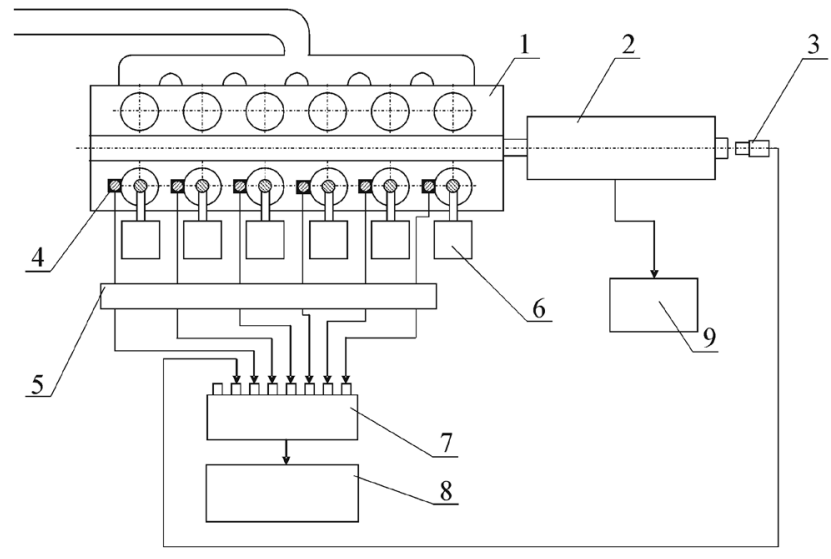

Fig. 10. The scheme of a measuring test stand: 1 - engine, 2 - alternators, 3 - angle encoder, 4 - vibration transducer, 5 - charge amplifier, 6 -injection pump, 7 - data acquisition card, 8 - computer, 9 - water resistor with a control system

Rys. 10. Schemat stanowiska pomiarowego: 1 - silnik spalinowy, 2 -prądnice, 3 -znacznik kąta obrotu watu korbowego, 4-przetwornik drgań, 5-wzmacniacz ładunku, 6-pompa wtryskowa, 7 - karta pomiarowa, 8-komputer, 9-opornik wodny wraz z uktadem sterowania 

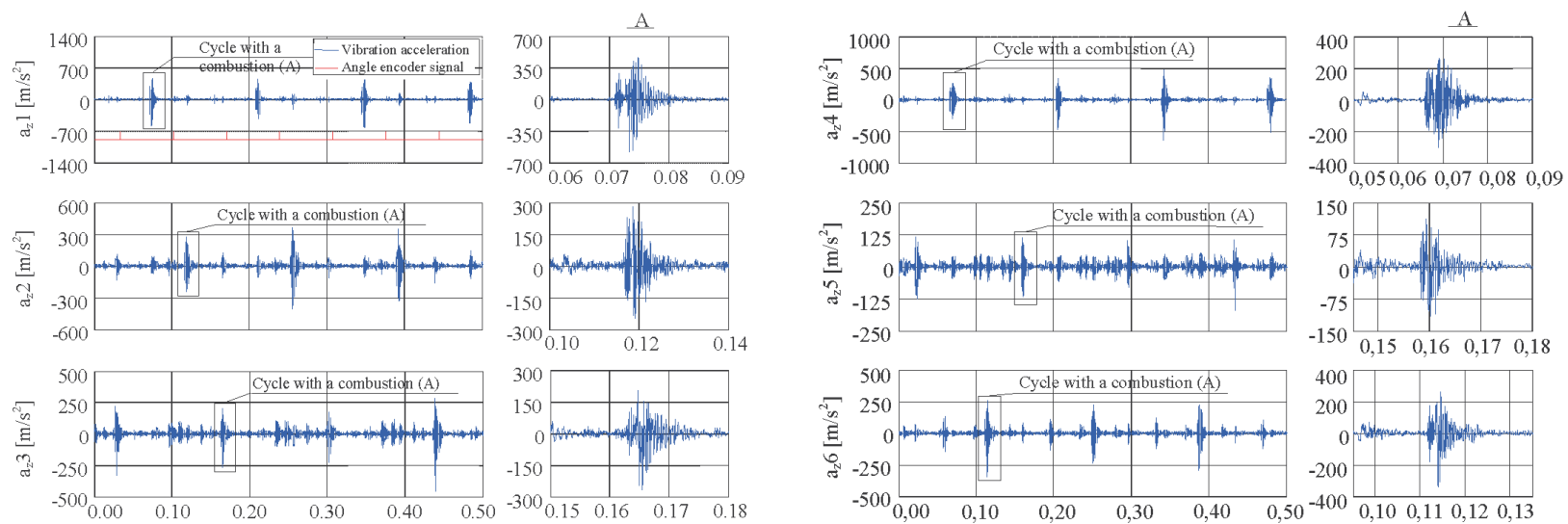

$\mathrm{t}[\mathrm{s}]$

$\mathrm{t}[\mathrm{s}]$
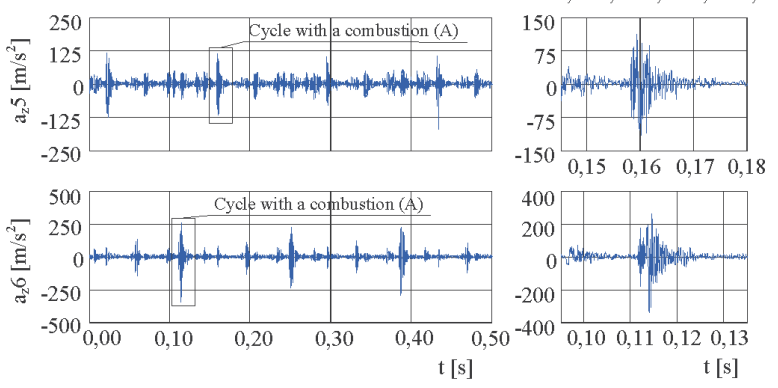

Fig. 11. Example vibration acceleration runs in the $\mathrm{Z}$ dimension $\left(\mathrm{a}_{\mathrm{z}}\right)$ of the cylinder heads nr $1-6$ of the 2112 SSF diesel locomotive engine $\left(\mathrm{n}=900 \mathrm{rpm}\right.$ and $\left.\mathrm{M}_{\mathrm{o}}=2674 \mathrm{~N} \cdot \mathrm{m}\right)$

Rys. 11. Przykładowy przebieg wartości przyspieszenia drgań w kierunku Z (a) na głowicach cylindrów 1-6 silnika spalinowego typu 2112 SSF lokomotywy spalinowej $(n=900 \mathrm{obr} / \mathrm{min} i \mathrm{M}=2674 \mathrm{~N} \cdot \mathrm{m})$
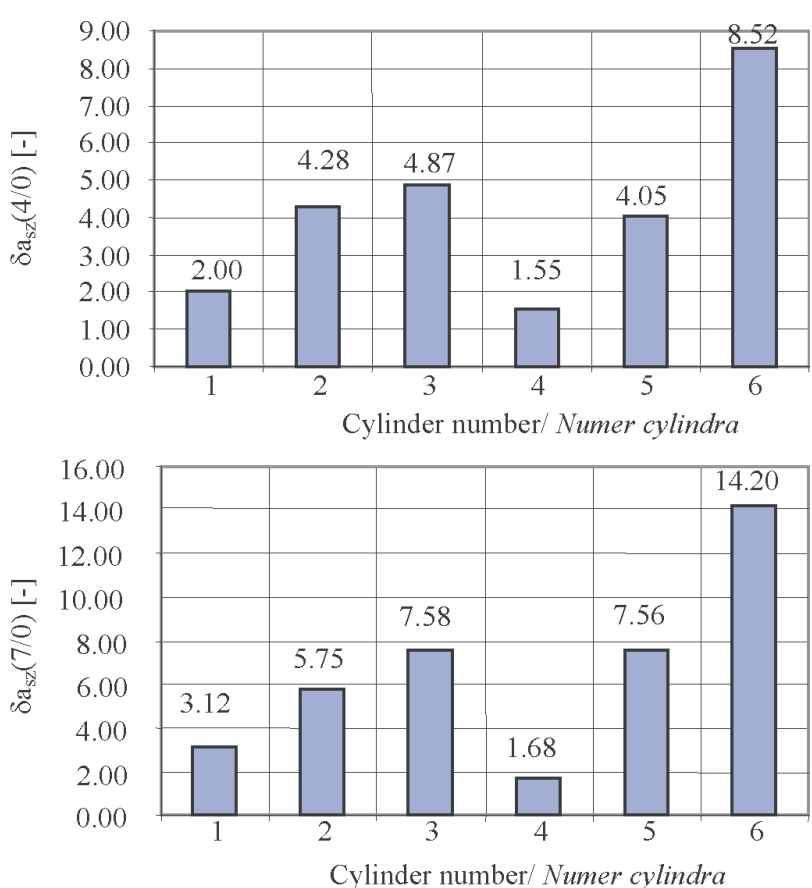
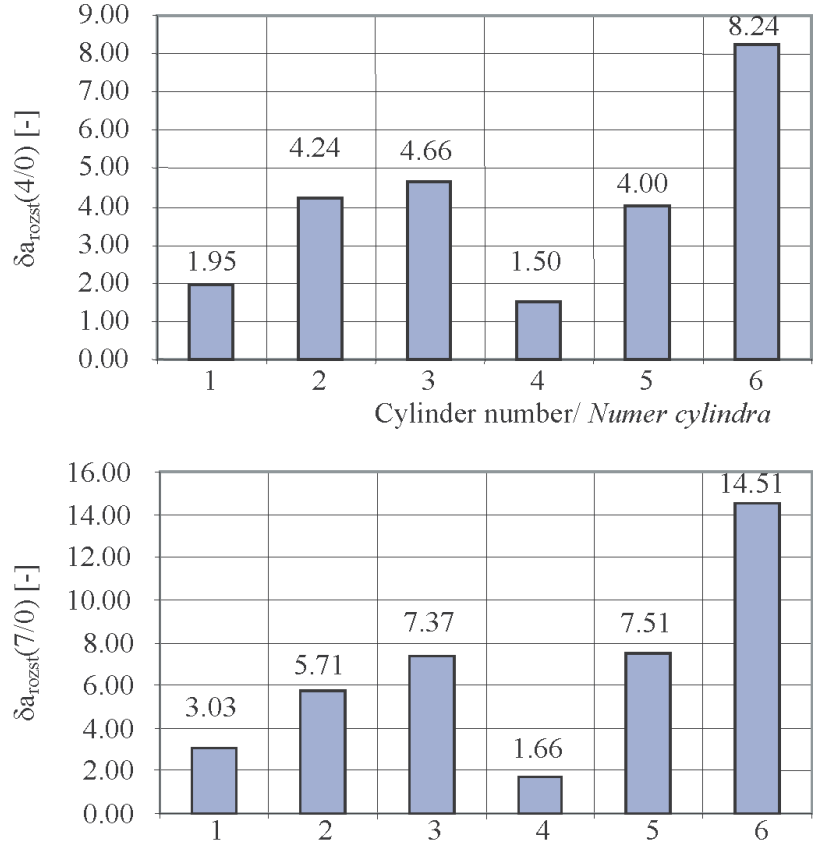

Cylinder number/ Numer cylindra

Fig. 12. The relative increase of the peak value (a) and peak-to-peak value (b) of the vibration acceleration of the chosen cylinder heads for the fourth $\left(n=900 \mathrm{rpm}, M_{0}=2674 \mathrm{~N} \cdot \mathrm{m}\right)$ and seventh $\left(\mathrm{n}=1080 \mathrm{rpm}, \mathrm{M}_{\mathrm{o}}=4067 \mathrm{~N} \cdot \mathrm{m}\right)$ driving controller position in relation to the idling run for the $2112 \mathrm{SSF}$ engine

Rys. 12. Względne zwiększenie wartości szczytowej (a) i międzyszczytowej (b) przyspieszenia drgań na głowicach wybranych cylindrów silnika $2112 \mathrm{SSF}$ dla czwartej $\left(n=900 \mathrm{obr} / \mathrm{min}, M_{o}=2674 \mathrm{~N} \cdot \mathrm{m}\right)$ i siódmej $\left(n=1080 \mathrm{obr} / \mathrm{min}, M_{o}=4067 \mathrm{~N} \cdot \mathrm{m}\right)$ pozycji nastawnika jazdy odniesione do biegu jałowego silnika

The fourth cylinder occurred to have the lowest and the sixth cylinder the highest relative change of the point measures in the case when the effective power had changed. These two cylinder numbers represents the worst and best conditions for misfire detection strategy. The fourth cylinder will be considered in the next parts of the paper.

When a misfire event occurred (a misfire was being realized in an engine by cutting off the fuel injection in a cylinder), it caused that the vibration signal amplitude
Sposób pomiaru sygnałów był podobny do tego, który zastosowano w badaniach podstawowych na hamowni silnikowej. Moment obrotowy i moc użyteczna silnika były wyznaczane i kontrolowane $\mathrm{z}$ wykorzystaniem stanowiska $\mathrm{z}$ opornikiem wodnym.

\subsection{Wyniki badań $i$ analiz}

Pierwszy i drugi etap badań na lokomotywie spalinowej dowiodły, iż sygnał drganiowy może być zastosowany do bieżącej oceny zjawisk wypadania zapłonu, które występują 
decreased irrespective of the cylinder number and working conditions. The relative decreases of: the peak and peak-topeak values, defined by the equation (7), obtained for the diesel locomotive engine pointed at the very high precision and reliability of the misfire detection with the help of vibration methods. In the case of the fourth cylinder, misfire event occurrence made the peak value decrease from 8 to 31 times regarding to the value for combustion process. In the case of the peak-to-peak value relative decrease of this measure was from 9 to 32 (Fig. 13).

a)

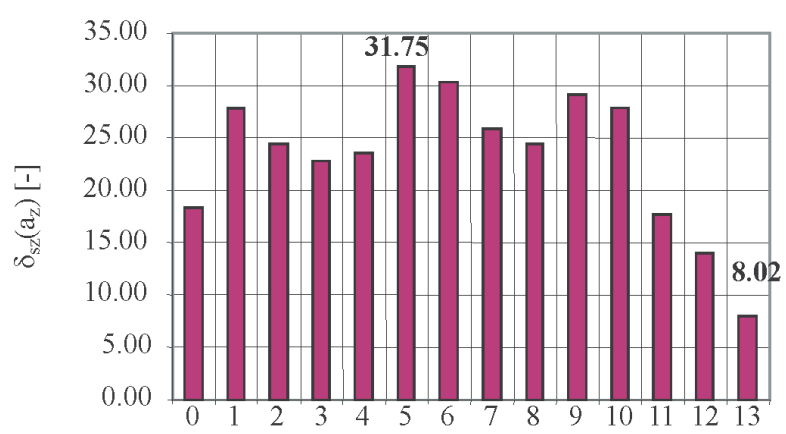

Controller position number/ Numer pozycji nastawnika jazdy

b)

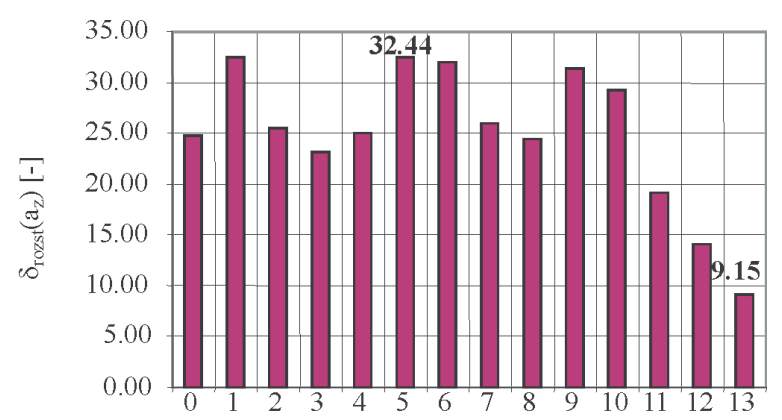

Controller position number/Numer pozycji nastawnika jazdy

Fig. 13. The relative decrease of the peak (a) and peak-to-peak (b) values as a result of the misfire events occurrence for different working point of the 2112 SSF engine

Rys. 13. Względne zmniejszenie wartości szczytowej (a) i międzyszczytowej (b) w wyniku braku zapłonu dla różnych punktów pracy silnika 2112 SSF

\section{Conclusions}

The research conducted at the engine test stand allowed to determine possibility of using vibration signal for misfire detection, define where the measurement sensors should be put at the engine and in what direction signals should be recorded. Additionally it has been proved that vibration acceleration ought to be used as a measurement signal and the simple dimensional point measures of the vibroacoustic process can describe changes occurring as a result of the misfire very well. They may constitute the basis for the realization of the diagnostic procedure of misfire detection within the on-board diagnostic systems - OBD.

The monitoring of the combustion process based on chosen vibration signal parameters allows an unambiguous podczas pracy silnika. Zapłon powoduje impulsowe zmiany amplitud sygnału drganiowego, proces spalania ma swoje odzwierciedlenie w sygnale drganiowym. Sygnał drganiowy jest jednoznaczny w każdym cyklu pracy niezależnie od numeru cylindra, co potwierdza wiarygodność metody $\mathrm{w}$ odniesieniu do procedur detekcji stosowanych dla wielocylindrowych silników ZS (rys. 11).

Zmiany mocy użytecznej powodowały zmiany dynamiki estymatorów punktowych sygnału drganiowego. Oznacza to, że parametry sygnału drganiowego podążają za zmianami wartości mocy (momentu obrotowego i prędkości obrotowej). Wzrost mocy użytecznej powodował wzrost wartości szczytowej i międzyszczytowej w każdym z cylindrów. Miarę punktową dla każdego z punktów pracy silnika odniesiono do miary punktowej uzyskanej dla pracy silnika w warunkach biegu jałowego (rys. 12).

Dla cylindra nr 4 odnotowano najmniejszą, a dla cylindra nr 6 największą zmianę miar punktowych w przypadku zmiany wartości mocy użytecznej silnika. Powyższe dwa cylindry reprezentują najgorsze i najlepsze warunki wykrywania braku zapłonu w silniku. W dalszej części artykułu będzie brany pod uwagę cylinder nr 4 .

Gdy występowało wypadanie zapłonu (brak zapłonu był realizowany w silniku przez odcinanie dopływu paliwa do cylindra), następowało zmniejszenie wartości amplitudy sygnału drganiowego odpowiednio do numeru cylindra $i$ warunków pracy silnika. Względne zmniejszenie wartości szczytowej i międzyszczytowej określone zależnością (7), uzyskane dla silnika spalinowego lokomotywy, potwierdziło bardzo dużą precyzję i wiarygodność wykrywania zjawisk wypadania zapłonów za pomocą metod drganiowych. W przypadku cylindra nr 4 wystąpienie braku zapłonu powodowało zmniejszenie wartości szczytowej od 8 do 31 razy w odniesieniu do wartości uzyskanej dla prawidłowego procesu spalania. Dla wartości międzyszczytowej względne zmniejszenie powyższej miary wyniosło od 9 do 32 (rys. 13).

\section{Podsumowanie}

Badania przeprowadzone na hamowni silnikowej pozwoliły na określenie możliwości zastosowania sygnału drganiowego do wykrywania braku zapłonu, zdefiniowanie miejsca mocowania przetworników pomiarowych na silniku, kierunku rejestracji sygnałów. Dodatkowo udowodniono, że jako sygnał pomiarowy należy zastosować przyspieszenie drgania, a także to, że proste wymiarowe miary punktowe procesu wibroakustycznego mogą bardzo dobrze opisać zmiany zachodzące w wyniku wystąpienia braku zapłonu w silniku. Mogą one być podstawą realizacji procedury diagnostycznej wykrywania zjawisk wypadania zapłonu w systemach OBD.

Kontrola procesu spalania oparta na wybranych parametrach sygnału drganiowego umożliwia jednoznaczne wykrywanie zjawisk wypadania zapłonów, co stanowi zaletę w odniesieniu do metod stosowanych obecnie. Badania przeprowadzone na silniku ZS lokomotywy spalinowej w warunkach jej eksploatacji potwierdziły dużą precyzję i dobrą jakość wykrycia wypadania zapłonu za pomocą przyspieszeń 
detection of misfires, which is an advantage of those methods over the currently used ones. The research conducted at the compression-ignition engine of the diesel locomotive in condition of its exploitation confirmed the high precision and quality of the misfire detection with the help of the vibration acceleration. The obtained results proved high precision of a diagnostic process for the each engine cylinder and the independence of a diagnosis from other interrupting factors. drgań. Uzyskane wyniki wskazały na dużą precyzję procesu diagnostycznego dla każdego z cylindrów i niezależność diagnozy od innych czynników zakłócających.

Artykut recenzowany

\section{Abbreviations and nomenclature/Wykaz skrótów i oznaczeń}

\begin{tabular}{|c|c|}
\hline $\mathrm{tth}$ & $\begin{array}{l}\text { geometric start of fuel delivering/geometryczny poczate } \\
\text { tłoczenia paliwa }\end{array}$ \\
\hline $\mathrm{BDC}$ & center/dolny martwy punkt położenia tłoka \\
\hline & ctor/współczynnik szczytu \\
\hline & amoczynny \\
\hline & dnica cylindra \\
\hline\{\} & $\begin{array}{l}\text { ean value after possible peak values of } \\
\text { r wartości średniej po możliwych war- } \\
\text { ych sygnału }\end{array}$ \\
\hline & \\
\hline & impulsowości \\
\hline & nik ksztattu \\
\hline /1 & $\begin{array}{l}\text { conficient which is the crankthrow divided by the lenght } \\
\text { rbowodu }\end{array}$ \\
\hline & torque/moment obrotowy \\
\hline & volutions per minute/prędkośc \\
\hline & -Board Diagnostics/poktadowy system $d$ \\
\hline
\end{tabular}

OBD On-Board Diagnostics/pokładowy system diagnostyczny

$\mathrm{P}_{\mathrm{cyl}} \quad$ cylinder pressure/ciśnienie $w$ cylindrze

$\mathrm{p}_{\mathrm{e}} \quad$ mean effective pressure/średnie ciśnienie użyteczne

$\mathrm{p}_{\mathrm{wtr}} \quad$ pressure of injection opening/ciśnienie otwarcia wtryskiwacza

S cylinder stroke/skok ttoka

SI spark-ignition/zapton iskrowy

t time, dynamic period/czas, okres dynamiczny

T signal period/czas

TDC top dead center/górny martwy punkt położenia ttoka

$\theta \quad$ object life cycle/cykl życia obiektu

$\mathrm{u}$ instantaneous signal value, type of the diagnostic parameters/wartość chwilowa sygnału, rodzaj parametru diagnostycznego

$\mathrm{u}_{\text {rozst }} \quad$ peak-to-peak value/wartość międzyszczytowa

$\mathrm{u}_{\mathrm{sk}} \quad$ effective value/wartość skuteczna

$\mathrm{u}_{\mathrm{sz}} \quad$ peak value/wartość szczytowa

$\mathrm{V}_{\mathrm{ss}} \quad$ engine displacement/objętość skokowa silnika

\section{Bibliography/Literatura}

[1] Cempel C.: The basics of the vibroacoustic diagnostic of machines. Scientific-Technical Publisher, 1982.

[2] Cempel C., Tomaszewski F.: Diagnostic of machines. Interdepartment Scientific Centre of the fixed assets exploitation, 1992.

[3] Korbicz J.: Diagnositc of processes. Models, methods of artificial intelligence, applications. Scientific-Technical Publisher, 2002.

[4] Merkisz J.: OBD II system as a tool which allow meeting toxic emission norms during exploitation. The 5th Scientific-Technical Conference on: Diagnostic of automotive vehicles 2000, Katowice 2000.

Prof. Jerzy Merkisz, DSc, MEng. - Professor in the Faculty of Working Machines and Transportation at Poznan University of Technology.

Prof. dr hab. inż. Jerzy Merkisz - Profesor na Wydziale Maszyn Roboczych i Transportu Politechniki Poznańskiej.
[5] Merkisz J., Mazurek S.: On-board diagnostic system of automotive vehicles. Communication and Connection Publisher, Warsaw 2002.

[6] Merkisz J., Waligórski M., Boguś P.: Possibilities and conditions of the OBD alike systems application in diesel locomotives engines. The 29th International Conference on Internal Combustion Engines Kones 2003.

[7] Merkisz J., Waligórski M., Boguś P., Grzeszczyk R.: On-board diagnostic of misfire event in diesel locomotives engines. Quaterly scientific-technical magazine: Rail-vehicles, $n r$ 4/2002, 2002.

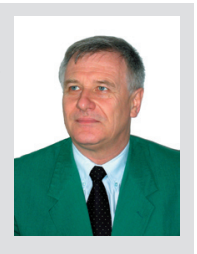

Mr Marek Waligórski, PhD, MEng. - doctor in the Faculty of Working Machines and Transportation at Poznan University of Technology.

Dr inż. Marek Waligórski-adiunkt na Wydziale Maszyn Roboczych i Transportu Politechniki Poznańskiej. 